\title{
Pension Reforms and Saving Gains in the United Kingdom
}

\author{
BRIGITTE GRANVILLE ${ }^{\mathrm{a}, *}$ and SUSHANTA MALLICK ${ }^{\mathrm{b}, * *}$ \\ ${ }^{\mathrm{a} U n i v e r s i t y ~ o f ~ L o n d o n ~ a n d ~}{ }^{\mathrm{b}}$ Loughborough University
}

(Received January 2004; In final form May 2004)

The empirical validity of the effect of pension reforms on domestic savings in the UK has been investigated using an Auto-regressive Distributed Lag (ARDL) model capable of testing for the existence of a long-run relationship regardless of whether the underlying time series are individually $\mathrm{I}(1)$ or $\mathrm{I}(0)$. The total savings response to change in pension savings is positive and significant, but an increase in occupational pension saving appears offset by a decrease in other forms of saving. This paper concludes that there is no firm evidence that aggregate savings increase considerably because of privately funded pension schemes.

Key words: Population aging, Retirement savings, Pension funds

JEL Codes: G23, H55, C50

\section{INTRODUCTION}

The purpose of this paper is to investigate the link between pension reforms and saving, with particular focus on whether the gradual privatisation of state pay-as-you-go (PAYG) schemes, started in the 1980s, has increased savings in the UK. ${ }^{1}$ Whether pension schemes are PAYG or funded, ultimately their financial viability depends on a sustainable rate of output growth, which in turn depends upon the pace of productivity growth. Barr (2002)suggests that the choice between government PAYG and funded schemes (private or public) matters much less than the capacity of the government to manage the economy effectively, to promote adequate growth of output, and to sustain a stable foundation for whatever pension system is adopted. However, assuming a sound growth-oriented policy environment, the impact of chosen pension arrangement savings will affect the extent of economic growth achieved. High saving rates are associated with growth performance, even if they do not on their own guarantee growth. Although financial liberalisation can enhance the efficiency with which saved resources are channelled into productive use, the suspicion that it may have contributed to the sharp decline in saving ratios observed in many industrial countries has focused attention on the impact of financial sector policy on saving. ${ }^{2}$

\footnotetext{
* Corresponding author. Centre for Business Management, Queen Mary, University of London, Mile End Road, London E1 4NS, UK; E-mail: b.granville@qmul.ac.uk

** Department of Economics, Loughborough University, Ashby Road, Loughborough, Leicestershire LE11 3TU, UK; E-mail: s.k.mallick@lboro.ac.uk

${ }^{1}$ The key reforms include the 1981 decision to index the basic state pension in line with prices rather than the greater of prices or earnings and the 1986 and 1995 Social Security Acts announcing cuts in the State EarningsRelated Pension scheme (SERPs), introduced in 1978, for people reaching the state pension age after 2000.
} 
Pension reforms gained momentum in the 1990s due to a combination of economic, fiscal, and demographic concerns. Those concerns centred on inadequate saving and one of the benefits claimed for the privatized defined contribution (DC) pension plan is that it raises national saving (Feldstein, 1996). Reducing unfunded public pensions can raise national saving and wealth directly, by reducing government debt, and indirectly increase saving through two other channels. First, the elimination of the payroll tax may lead to an increase in labour supply (by encouraging low-skilled workers to join the labour force) thus boosting GDP and increasing saving. Second, shifting to funded pension schemes may stimulate the capital market, leading to an increase in the efficiency of investment (higher rates of return) and thereby to an increase in economic growth and saving, depending on the extent of capital market development prior to the reforms. ${ }^{3}$

We measure the overall effect of the shift to funded pension schemes on the level of national savings, taking into account the potential impact both on individual savings behaviour and on the capital market because the shift to funded pensions on the capital market seems to arise more from changes in allocation rather than from changes in the level of savings.

This paper is organised as follows: section 2 provides an analytical framework for how to model the saving impact of pension privatization, along with discussion of the nexus between pension funds and capital markets. Section 3 presents the empirical analysis of the savings relationship and the findings on whether a higher funded element in pension provision does matter in stimulating national savings. The final section draws some policy recommendations.

\section{MODELING THE IMPACT OF FUNDED SCHEMES ON SAVINGS}

The impact of the pension system on individual saving has been a concern since Feldstein's (1974) pioneering paper, which centres around the funding status of social security and, in particular, on the degree to which an unfunded pension system reduces private saving. For Palley (1998), the way to finance social security that has the least effect on private savings is to cut payroll taxes and finance the public pension system from general tax revenues. If the pension system is financed through payroll taxes, then wages must grow as the number of retirees increases, but if the public pension scheme is financed out of the general income tax, and if income tax receipts are proportional to GDP, then the pattern of wage growth is no longer important. For the UK, however, Pitelis (1997) found that compulsory contributions from wage income reduce private savings. While theoretical arguments tend to be consistent with the view that higher private savings are associated with funding than with PAYG, convincing empirical support is missing (Hemming, 1999). The literature based on crosscountry empirical studies indicates only that long-term saving and investment are positively correlated but not whether growth drives saving or saving drives growth through the savinginvestment link. ${ }^{4}$

In the UK, the effect of the shift from PAYG provision to private funded provision has been, first, to reduce the level of benefits from the state schemes and, second, to increase the role and efficacy of private sector provision. ${ }^{5}$ (a schematic representation of the UK pension

\footnotetext{
${ }^{2}$ Honohan 1999, p. 71.

${ }^{3}$ See Orszag and Stiglitz, 2001.

${ }^{4}$ See Schmidt-Hebbel, 1999 for a review of the discussion, pp.14-15.

${ }^{5}$ Blake 2000, p. 241. Regulation of pension funds in the UK is undertaken by the occupational pension's regulatory body (OPRA), the Financial Services Authority (FSA), and the Government. See Davis, 2001 for more details on regulation of pension funds.
} 


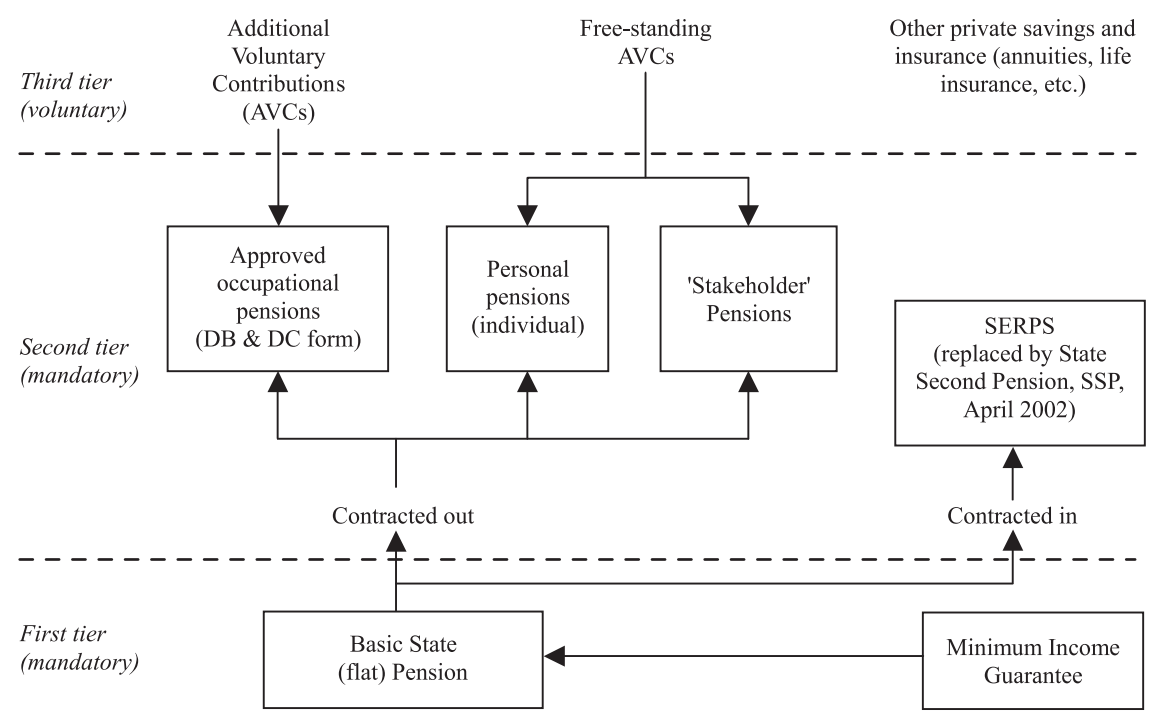

FIGURE 1 The Pension System in the UK, 2002.

Source: updated from Disney et al., 2001, p. 72.

Note: PAYG systems are transfer systems; through payroll taxes they transfer wealth from today's workers to today's retirees. With DB schemes, an employee's final benefit is based on a predetermined formula and the employee does not take direct investment risk. With DC schemes, instead of the final benefit level, the contribution level is set and is then invested at the risk of the employee. Stakeholder pensions - individual funded accounts intended primarily for people with earnings above $£ 9,000$ - are part of the more general trend from public to private provision that successive UK governments have been encouraging.

scheme in 2001 is shown in Figure 1). The overall structure of the UK pension system also has been influenced by the introduction of the accounting standard, FRS17, issued in November 2000 to be operational by 2005 . FRS17 aimed at introducing rules that are more stringent for mutual funds to provide more transparency regarding company pension schemes. ${ }^{6}$ The requirement for companies to show pension valuation swings in their reports and accounts has accelerated the recent trend away from defined-benefit (DB), or so-called "final-salary," schemes towards DC, or "money-purchase," schemes, effectively transferring the risk from the employer (or pension fund) to the individual. ${ }^{7}$ The net wealth of the household sector in the UK has shown strong growth in recent years, increasing by an average of 4.6 percent per year between 1987 and 2000 after adjusting for inflation. In 2000, the largest component of the net wealth of the household sector was holdings in life assurance and pension funds, followed by non-financial assets such as housing (Table 1). ${ }^{8}$ The reversal of the position from twelve years earlier when non-financial assets predominated is the result partly of strong growth in the take-up of private pensions and partly of the fall in the value of owner-occupied

${ }^{6} \mathrm{FRS} 17$ requires pension fund liabilities to be marked to market using the AA corporate bond yield as a benchmark. This would leave few diversification possibilities domestically, thereby making selective international bond and equity markets the most likely destination for pension funds. Companies must report on the balance sheet the total value of a surplus or deficit - when value of the financial assets cannot cover the liabilities. The introduction of FRS17 would not allow "smoothing," which means companies would need to look at the snapshot fair value at the end of each fiscal year.

${ }^{7}$ Almost half of the companies in the benchmark equity index FTSE 100 now no longer make final-salary schemes available to new employees. The pension return in a DC case would depend on the amount contributed by both the employee and the employer and how well the investment has performed.

8"Saving up for house purchase is analogous to saving up for retirement." (Deaton, 1999, p. 54). 
TABLE I Composition of the Net Wealth of the UK Household Sector.

\begin{tabular}{|c|c|c|c|c|c|c|}
\hline & \multicolumn{6}{|c|}{ (Percent) } \\
\hline & 1987 & 1991 & 1996 & 1998 & 1999 & 2000 \\
\hline $\begin{array}{l}\text { Financial assets Life assurance and } \\
\text { pension funds }\end{array}$ & 24.6 & 26.8 & 36.0 & 37.4 & 36.9 & 36.0 \\
\hline Securities and shares & 10.0 & 11.1 & 13.8 & 14.8 & 16.9 & 16.3 \\
\hline Currency and deposits & 15.8 & 16.8 & 16.5 & 14.7 & 13.3 & 13.9 \\
\hline Other assets & 2.6 & 2.8 & 2.4 & 2.0 & 1.8 & 1.9 \\
\hline $\begin{array}{l}\text { Non-financial assets net of total } \\
\text { liabilities }\end{array}$ & 47.0 & 42.5 & 31.3 & 31.1 & 31.1 & 31.9 \\
\hline Total net wealth & 100.0 & 100.0 & 100.0 & 100.0 & 100.0 & 100.0 \\
\hline$£$ billion at 2000 prices & 2,580 & 2,870 & 3,229 & 3,974 & 4,565 & 4,605 \\
\hline
\end{tabular}

Source: Office for National Statistics (ONS): www.ons.gov.uk

Note: Total net wealth adjusted to 2000 prices using the expenditure deflator for the household sector.

housing during the early 1990s. Despite the rise in household wealth, the aggregate household savings ratio in the UK declined during the 1990s. In general, saving rates in countries that implemented DC schemes have not risen after the reform (Samwick, 2000). The switch from social security pension towards private pension contributions over the last decades has not been accompanied by a significant rise in either retirement saving or total household saving in OECD countries. ${ }^{9}$

\subsection{An Analytical Framework}

In an accounting sense, saving equals disposable income less consumption and we can write the saving function $(\mathrm{S})$ as:

$$
S=\alpha_{0}+\alpha_{1} X
$$

where $\alpha_{0}$ and $\alpha_{1}$ are parameters and $\mathrm{X}$ is a vector of exogenous variables, including income.

Privatization of the pension system may affect savings by boosting capital accumulation, which in turn affects income. Savings can be decomposed into retirement savings (SR) and other savings ( $\mathrm{SO}$ ): $S=S R+S O$, and there may be substitution between SR and SO.

Assuming that SR is exogenously determined, in other words, that retirement saving is determined solely by policy factors as is the case with state PAYG and private DB schemes, we can write

$$
S O=\alpha_{0}+\alpha_{1} X-\alpha_{2} S R
$$

where $\alpha_{2}$ indicates the extent of substitution between SO and SR. If $\alpha_{2}=1$, then retirement savings fully offset other savings. Total saving is unaffected by increases in pension wealth. Assuming $\alpha_{2}<1$, i.e. that SO and SR are not perfect substitutes, the savings function $\mathrm{S}$ can be written as:

$$
S=\alpha_{0}+\alpha_{1} X+\left(1-\alpha_{2}\right) S R
$$

${ }^{9} \mathrm{OECD}, 2002$, p. 81. 
For the UK, however, with the privatisation of state pension and the introduction of the FSR17 requirements leading to the elimination of final salary company pension, we cannot assume that retirement saving is exogenous. Therefore, we need to consider the factors that drive the process of saving for retirement. We know of no empirical research that has investigated the effect of endogenous retirement savings on total savings in a time-series quantitative framework, which could partly be due to data difficulties inherent in savings measurement. ${ }^{10}$

The set of other explanatory variables (X) takes into account the different macroeconomic environments, habits, policy incentives and so on that could affect savings patterns. The systematic determinants of private savings - actual and expected growth rates and the terms of trade - are beyond the direct control of policies.

The impact of interest rates on household savings is ambiguous because income and substitution effects work in opposite directions. In the standard neoclassical view, as higher interest rates increase the opportunity cost of consumption, households increase savings (the substitution effect); however, with higher interest rates, positive savers increase consumption because of their rising wealth (the income effect). Empirical evidence from cross-country studies shows that interest rates have little or no effect either on saving (Edwards, 1996; Masson, Bayoumi and Samiei, 1998) or on consumption levels (Deaton, 1992).

According to the life-cycle model ( $\mathrm{LCH})$, the higher the ratio of the elderly population to the working-age population, the lower will be the aggregate saving rate because the old are retired and do not save while the young work and do save. Observed declining saving rates in OECD countries cannot be attributed to income going from young savers to old non-savers, however, because: "in the United States and the UK, where it is possible using survey data to give some account of who is doing the saving, the decline does not appear to be a compositional phenomenon; instead, saving fell for all groups". ${ }^{11}$ Moreover, Paxson (1996) seems to find that there is not such a negative correlation between saving and age.

The budget deficit negatively affects the overall saving rate when the savings of the private sector (mostly households) do not fully offset the deficit. ${ }^{12}$ People could react to government deficits (negative savings) by increasing their saving in anticipation of higher taxes (stemming from increased debt-servicing costs) or by reducing savings in anticipation of the faster inflation that will eventually occur. Similarly, changes in private savings are likely to offset changes in government savings, but the significance of this offset remains controversial. However, the national accounting identity $(\mathrm{CA}=\mathrm{S}-\mathrm{I})$ suggests that a current account surplus (deficit) causes domestic saving to rise (fall) implying savings outflows (inflows of foreign capital).

\subsection{The Pension Fund-Capital Market Nexus}

In this section, we highlight the linkages that private pension funds can provide in fostering capital market development across debt, equity, and bank markets in the UK. Raising long term private saving effectively requires increasing the assets of long-term instruments like pensions, life insurance, and mutual funds. Depending on how they are invested, increased retirement savings could reduce the rates of return on such assets, and thereby drive down the market value of long-term savings assets.

\footnotetext{
${ }^{10}$ For problems with saving data, see Schmidt-Hebbel and Serven, 1999, p.24.

${ }^{11}$ Deaton, 1999, p. 45. See Attanasio and Banks 2001 for a survey on household saving behaviour.

${ }^{12}$ This is the notion behind the "Ricardian Equivalence Hypothesis" first proposed by Robert Barro (1974).
} 
Using a panel set of data for ten countries over the period 1982-1993, Bailliu and Reisen (2000) find that the build-up of pension assets exerts a positive and statistically significant effect on aggregate saving rates. Private pension fund assets largely invested in equities have grown in many OECD countries in recent years, although the size of such assets relative to GDP differs widely across countries. Pension fund assets are as high as 112.6 percent of GDP in the Netherlands but as low as 3 percent in Germany (Figure 2). Pension fund assets in the UK amount to 85.1 percent of GDP, with DB schemes comprising around half of total pension assets (Figure 2). The share of pension funds and life insurance in gross financial saving has risen over the past 30 years, particularly after the sector was opened to the private sector. Currently British pension assets amount to around GBP1.1 trillion, or about US $\$ 2$ trillion (compared to American pension assets of US\$5.1 trillion). ${ }^{13}$ Personal pensions have grown substantially over the last twenty years, increasing from 12 to over 20 percent of total pension assets between 1988 and 1995. ${ }^{14}$

The Myners (2001) Report, which outlined codes of conduct and principles for the UK pension industry, called for increased allocation of pension funds to risky but high yield asset classes including investment in venture capital and private equity. Doing this, however, makes it likely that equity market volatility and changes in pension fund legislation, could trigger wide-scale re-allocations of pension fund assets (see Table 2). ${ }^{15}$ To reduce the volatility of maturing pension fund valuation swings, companies ${ }^{16}$ have been

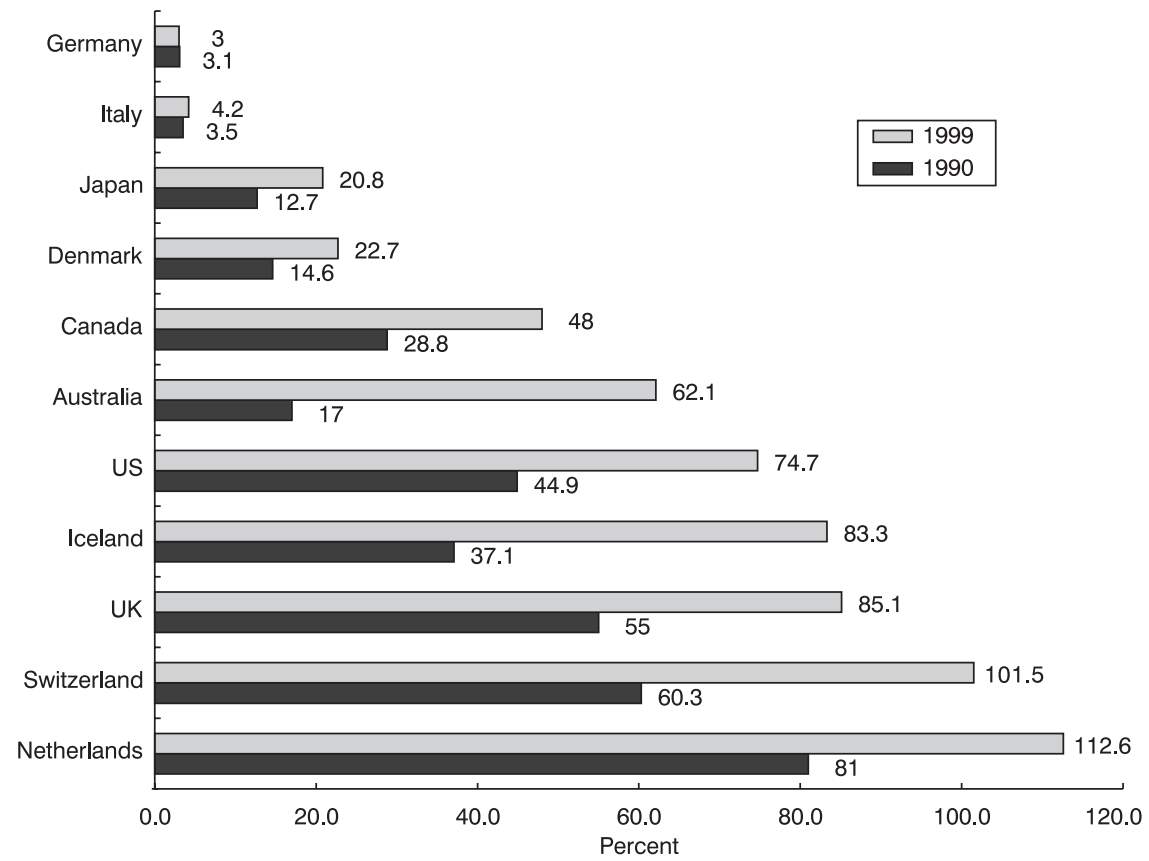

FIGURE 2 Pension fund assets as a percentage of GDP in OECD economies, 1990 and 1999.

\footnotetext{
${ }^{13}$ Pickering, 2002, p. 69.

${ }^{14}$ See Sandler, 2002.

${ }^{15}$ The FTSE 100, the key stock market index in the UK, lost 25 percent of its value in 2002 amid fears of global uncertainty, corporate scandals, and economic stagnation, while the benchmark MSCI Euro-sterling Credit Index (ESCI) has given a positive total return of 9.8 percent in 2002, following 6.4 percent return in 2001 .

${ }^{16}$ According to newswires, the UK Boots group with a pension fund valuation of about GBP 2.3 billion sold its entire portfolio of equities and switched the allocation into long dated fixed income bonds, including World Bank and European Investment Banks bonds.
} 
TABLE II Ownership of UK equities.

\begin{tabular}{lrrrrrrrrr}
\hline & \multicolumn{1}{c}{ (Percent) } \\
\cline { 2 - 10 } & 1963 & 1975 & 1981 & 1989 & 1994 & 1997 & 1998 & 1999 & 2000 \\
\hline Pension funds & 6.4 & 16.8 & 26.7 & 30.6 & 27.8 & 22.1 & 21.7 & 19.6 & 17.7 \\
Insurance companies & 10.0 & 15.9 & 20.5 & 18.6 & 21.9 & 23.5 & 21.6 & 21.6 & 21.0 \\
Other financial institutions & 13.9 & 15.3 & 10.7 & 9.3 & 10.5 & 10.7 & 9.6 & 10.7 & 9.8 \\
Individuals & 54.0 & 37.5 & 28.2 & 20.6 & 20.3 & 16.5 & 16.7 & 15.3 & 16.0 \\
Other personal and public & 8.7 & 8.9 & 10.3 & 8.1 & 0.2 & 3.2 & 2.8 & 3.5 & 3.1 \\
sector companies & & & & & & & & & \\
Foreign & 7.0 & 5.6 & 3.6 & 12.8 & 16.3 & 24.0 & 27.6 & 29.3 & 32.4 \\
Total & 100.0 & 100.0 & 100.0 & 100.0 & 100.0 & 100.0 & 100.0 & 100.0 & 100.0 \\
Value of FTSE all-share index & 27 & 45 & 92 & 470 & 690 & 1,209 & 1,334 & 1,732 & 1,452 \\
\hline
\end{tabular}

Source: UBS Global Asset Management.

Note: "Other financial institutions" includes banks and unit and investment trusts.

switching assets from equities into the government and corporate bond markets. ${ }^{17}$ Given that 46 percent of UK pension funds are invested in UK equities and 25 percent in overseas equities, (making a total equity exposure of about 70 percent), the UK equity market is at significant risk if a wholesale portfolio shift takes place among pension funds (Table 3).

Funded pension systems are prone to such capital market risks as variation in real rate of return, inflation risk if claims are expressed in nominal terms, and exchange rate risk if claims are denominated in a different currency than consumption, Dutta et al., (2000) argue that mixed funded-unfunded systems are desirable as they enable risk diversification. Moreover, because with funded schemes benefits are based on long-term capital accumulation and financial market performance, a DC fully funded pillar is a useful supplement in a multipillar system for the accumulation of retirement savings. These funds should be privately managed to minimize dependence on public sector institutions and avoid government dominance of the economy and financial markets (Vittas, 2002).

TABLE III Composition of UK pension portfolio by type of asset, 1989-2001.

\begin{tabular}{|c|c|c|c|c|c|c|c|c|c|c|c|c|c|}
\hline & \multicolumn{13}{|c|}{ (Percent) } \\
\hline & 1989 & 1990 & 1991 & 1992 & 1993 & 1994 & 1995 & 1996 & 1997 & 1998 & 1999 & 2000 & 2001 \\
\hline UK equities & 52 & 52 & 55 & 56 & 57 & 54 & 55 & 53 & 53 & 51 & 51 & 48 & 46 \\
\hline Foreign equities & 20 & 18 & 20 & 21 & 24 & 23 & 22 & 22 & 20 & 20 & 24 & 23 & 25 \\
\hline UK bonds & 8 & 8 & 7 & 6 & 4 & 5 & 6 & 6 & 7 & 9 & 9 & 10 & 10 \\
\hline UK index linked & 3 & 3 & 3 & 3 & 3 & 4 & 5 & 5 & 5 & 6 & 4 & 6 & 7 \\
\hline Foreign bonds & 2 & 2 & 3 & 3 & 3 & 4 & 3 & 3 & 3 & 4 & 4 & 4 & 3 \\
\hline Cash & 6 & 7 & 4 & 4 & 4 & 4 & 4 & 6 & 7 & 5 & 4 & 4 & 3 \\
\hline Real estate & 9 & 10 & 8 & 7 & 5 & 6 & 5 & 5 & 5 & 5 & 4 & 5 & 6 \\
\hline Total pension assets & 100.0 & 100.0 & 100.0 & 100.0 & 100.0 & 100.0 & 100.0 & 100.0 & 100.0 & 100.0 & 100.0 & 100.0 & 100.0 \\
\hline
\end{tabular}

Source: UBS Global Asset Management.

${ }^{17}$ The gilt market is about GBP207 billion in size and the corporate bond market around GBP11.1 billion. 
Some OECD countries, including the UK, have introduced special savings programs to encourage participation in securities investment. ${ }^{18}$ To make it easier for people to save for retirement, however, regulatory changes, beginning with eliminating the state pension age of 65 and introducing tax-free saving incentives, are needed. Booth and Cooper (2002) compared the costs imposed on DC pension schemes by existing tax regimes for saving (such as the ISA regime) and by theoretical regimes (such as a pure expenditure tax and a comprehensive income tax). They conclude that an expenditure tax (which exempts investment returns) is an appropriate benchmark tax regime for pension saving, and that other tax regimes impose additional financial as well as administrative costs.

While the risks for funds based on stocks and bonds are reasonably well understood, the risks associated with investment in housing are not. Many owner-occupiers especially in the UK see their house as an asset for old age and see housing wealth as a shield against inflation, even though it is exposed to its own variant of capital market risk. Indeed, house prices may fall relative to consumption. ${ }^{19}$ The evidence that it is possible to forecast both house prices and relative rates of return in housing is consistent with the hypothesis that housing markets are far from efficient (Muellbauer and Murphy, 1997). If people view housing assets as a substitute for retirement savings, then fluctuations in housing wealth will affect how much of their total savings they allocate to pension savings (to private retirement accounts).

With the development of an institutional investor base, private pension funds contribute to capital market development (or total market capitalization) by promoting contractual savings. ${ }^{20}$ The literature is not clear, however, on the direction of causality between contractual savings and capital market development, although there is evidence that these contractual savings do contribute to financial and stock market development and thereby have knock-on effects on economic growth (see Catalan et al., 2000). ${ }^{21}$

\section{EMPIRICAL ANALYSIS}

Referring back to Equation (1) we had the level of national savings as a function of the level of savings for retirement and a vector of exogenous variables, $\mathrm{X}$.

$$
S=\alpha_{0}+\alpha_{1} X+\left(1-\alpha_{2}\right) S R
$$

Based on our discussion in the previous section regarding the factors that affect savings behaviour, $\mathrm{X}$ should include the effect of interest rates, credit market development, the government budget, the availability of retirement benefits from the public pension system, and the age composition of the population.

\subsection{Definitions of Variables and Time Series Properties of Data}

Specifically, we analysed annual data on savings and these other factors in the UK over the period 1978-2000. We compiled data from ONS, the UK Department for Work and

\footnotetext{
${ }^{18}$ The UK's ISA (Individual Savings Account) and France's PEA (Plan d'Epargne en Action) are good examples.

${ }^{19}$ Börsch-Supan and Brugiavini, 2001, p. 127.

${ }^{20}$ Testing the main influences on the size of the pension asset/GDP ratio in a broad group of OECD countries, Davis (1996) finds that: (1) the generosity of social security has a negative effect on the size of pension funds; (2) reducing the favourability of tax treatment in pensions reduces the size of funds; (3) mandatory provision increases the size of funds; and (4) system maturity is associated with a larger size of funds.

${ }^{21}$ Using annual time series (1979-1994) for Chile, Holzmann (1997) provided preliminary evidence that coincides with the claim that pension reform there contributed to financial market development and to a more diversified portfolio, but he also found that the reform's direct impact on saving was low, and initially even negative. For conflicting evidence on whether a private system increases national saving, see Mesa-Lago, 2002, p. 1316-1317.
} 
Pensions, and International Financial Statistics of IMF, to calculate annual time series for the following variables:

- SAVR is the aggregate saving rate based on the current account definition of savings as the residual difference between total income and consumption. We chose this definition for a time series study, rather than the capital account measure that defines savings as changes in net wealth derived from flow-of-funds data (Table 1), because survey and flow of funds data could refer to a limited period or at a particular point in time.

- PENSION is defined as the ratio of net investment by private pension funds over the working-age population and it should reflect the growth in private pension assets with the UK pension reforms. The ONS publishes such pension fund investment data in flow form. This approach contrasts with Bailliu and Reisen (2000) who define changes in funded pension wealth based on assets of pension funds. These data are defined as the market value of net pension fund assets and, therefore, they include capital gains/ losses.

- RINT is the real interest rate defined by the Fisher relation,

$1+r=\frac{1+i}{1+\pi^{e}} \quad$ or,$r=\frac{i-\pi^{e}}{1+\pi^{e}}$, where $r$ denotes the real interest rate, $i$ the nominal interest rate and $\pi^{\mathrm{e}}$ is the expected inflation rate. We use the current CPI inflation rate as a proxy for $\pi^{\mathrm{e}}$ and the T-bill rate as a measure of $i$.

- PAYG is defined as the real expenditure on public pension benefits divided by the population aged 65 (men) 60 (women) and over and is a measure of the level of public pension benefits per elderly person.

- The dependency ratio, DEP, calculated as the ratio of persons over 64 to persons aged 20-64 years.

- FIS is the government's fiscal balance to control for the effect of government deficits on private savings.

- GROWTH is per capita GDP growth.

- CREDIT is domestic credit to the private sector as a percent of GDP to indicate the liquidity constraint on households

As we look at the relationship among these variables over time, we need to examine their properties as time-series and choose appropriate estimation techniques. Augmented DickeyFuller (ADF) tests suggest that all the variables are non-stationary in levels and that it is not possible to reject the null hypothesis of integration of order one at less than one percent significance level. We performed unit root tests on the first differences of the variables to check for the presence of $\mathrm{I}(2)$ processes. The results "stationarity" in first differences for all variables except PENSION, FIS, and CREDIT, which were found to be I(2) (Table 4). In some cases the null hypothesis of a unit root in first differences was accepted by a relatively small margin, however, we assumed I(1) for all variables excluding DEP and PAYG, which were $\mathrm{I}(0)$.

Since the ADF test is an asymptotic test, it may not be appropriate for our small sample. Nevertheless, because we found the variables in our sample to be of different orders of integration, the ARDL model, as explained, below is most suitable to carry out further investigation. This analysis led us to choose the following general specification of the savings relation for our sample:

$$
S A V R_{t}=f\left(\text { PENSION }_{t-i}, \text { RINT }_{t-i}, F I S_{t}, \text { GROWTH }_{t}, \text { CREDIT }_{t}, P A Y G_{t}, D E P_{t-i}\right) ; i=0,1
$$


TABLE IV Results of ADF unit root test.

\begin{tabular}{|c|c|c|c|c|c|c|c|}
\hline \multirow[b]{2}{*}{ Variable } & \multicolumn{2}{|c|}{ ADF in Levels } & \multicolumn{2}{|c|}{ ADF in 1 st differences } & \multicolumn{2}{|c|}{ ADF in 2nd differences } & \multirow[b]{2}{*}{$\sim I()$} \\
\hline & $\begin{array}{c}\text { Without } \\
\text { trend }\end{array}$ & $\begin{array}{l}\text { With } \\
\text { trend }\end{array}$ & $\begin{array}{c}\text { Without } \\
\text { trend }\end{array}$ & $\begin{array}{l}\text { With } \\
\text { trend }\end{array}$ & $\begin{array}{c}\text { Without } \\
\text { trend }\end{array}$ & $\begin{array}{l}\text { With } \\
\text { trend }\end{array}$ & \\
\hline SAVR & -2.177 & -2.548 & $-3.016^{*}$ & -2.978 & $-4.369 * *$ & $-4.345^{*}$ & $\mathrm{I}(1)$ \\
\hline PENSION & -1.913 & -1.988 & -2.482 & -2.523 & $-4.236^{* *}$ & $-4.103^{*}$ & $\mathrm{I}(2)$ \\
\hline DEP & -2.606 & $-4.204 *$ & -1.727 & -0.286 & -2.033 & $-4.263^{*}$ & $\mathrm{I}(0)$ \\
\hline PAYG & -1.920 & $-4.057 *$ & -2.945 & -3.126 & $-3.664 *$ & -3.469 & $\mathrm{I}(0)$ \\
\hline RINT & -2.284 & -1.832 & $-3.596^{*}$ & $-5.033^{* *}$ & $-6.076^{* *}$ & $-5.775^{* *}$ & $\mathrm{I}(1)$ \\
\hline FIS & -1.902 & -1.907 & -1.861 & -2.014 & $-3.515^{*}$ & -3.579 & $\mathrm{I}(2)$ \\
\hline GROWTH & $-3.651^{*}$ & $-3.749 *$ & $-5.067 * *$ & $-4.947 * *$ & $-4.651 * *$ & $-4.389 *$ & $\mathrm{I}(1)$ \\
\hline CREDIT & -1.074 & -1.405 & -2.437 & -2.522 & $-4.745^{* *}$ & $-4.556^{* *}$ & $\mathrm{I}(2)$ \\
\hline
\end{tabular}

Notes: ADF unit root test is based on one lag except DEP and PAYG, which include 2 lags; $* * \& *$ denote $1 \%$ and $5 \%$ significance levels respectively. Critical values are: $5 \%=-3.0114,1 \%=-3.7856$ (without trend) and $5 \%=-3.645,1 \%=-4.469$ (with trend).

\subsection{Cointegration Analysis}

We use the co-integration method, which establishes the existence of a unique long-run equilibrium relationship between the variables. Although we have strong theoretical reasons for believing that the flow of pension assets and other variables influence savings, which in turn impacts investment, we cannot a priori exclude the existence of some reverse causality. Moreover, there could be important cross effects between pension assets and savings that could be captured by estimating the system as a vector autoregression (VAR) model. Given the limited number of observations (22) and the many variables involved (8), we chose the Autoregressive-Distributed Lag (ARDL) approach of Pesaran and Shin (1999) rather than the Johansen-type VAR model $(1988,1996)$. The ARDL approach allows for inclusion of deterministic/exogenous regressors in the cointegrating relation. Estimation is carried out using Microfit version 4.00 (see Pesaran and Pesaran, 1997).

The first step is to verify the existence of a long-run relation by computing the Wald statistic to test the joint significance of the lagged levels of the variables in the error correction form of the underlying ARDL model explaining SAVR. Since the Wald test statistic $\left[\chi^{2}(8)=\right.$ $64.8597(0.00)$ ] exceeds the upper bound of the critical value (CV) band at $1 \%$ significance level [24.215 to 34.367], we can reject the null of no long-run relationship between the variables irrespective of the order of their integration. ${ }^{22}$ This estimated test statistic implies that there is a stable long-run relationship explaining SAVR. As long as the underlying ARDL model is free of serial correlation (taking the lag structure of the right hand side variables into consideration), endogeneity of SAVR is not a problem although the test statistic rejects the null hypothesis, explaining PENSION, at a higher significance level. ${ }^{23}$ Given the existence of co-integration with SAVR as the endogenous variable, the second stage is to estimate the

\footnotetext{
${ }^{22}$ Similarly, $\chi_{8}^{2}$ (pensionl SAVR, .....) $=39.2262$ is greater than the upper bound $\mathrm{CV}$ at $1 \%$ significance level, while $\chi_{8}^{2}\left(\right.$ rintl SAVR,.....) $=25.7832$ and $\chi_{8}^{2}$ (growthl SAVR,..,..) $=27.0712$ are less than the upper bound CV (28.421) at 5 percent level respectively, but in case of all other variables, the test statistic is less than the lower bound of the CV 16.279 at 10 percent significance level. They are as follows: $\chi_{8}^{2}$ (fisl SAVR, ....) $=11.8847 ; \chi^{2}{ }_{8}$ (creditl $\operatorname{SAVR}, \ldots, ..)=7.5618 ; \chi_{8}^{2}($ paygl SAVR $, \ldots, .)=.9.2295 ; \chi_{8}^{2}(\operatorname{depl} \operatorname{SAVR}, \ldots, .)=$.8.0373 .

${ }^{23}$ This, however, proves that retirement savings can be endogenous and there could be a long-term relation explaining the pension savings.
} 
ARDL model in order to derive the long run and short-run coefficient estimates. We determined the order of the ARDL model by means of model selection procedures such as Akaike, Schwarz, and the adjusted R-square statistic. Equation (3) below presents the coefficients obtained from estimating the selected ARDL $(0,1,1,0,0,0,0,1)$ model using the Schwartz Bayesian Criterion allowing maximum one lag for each variable. T-values are in parentheses below the coefficients.

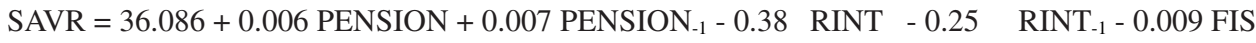

$$
\begin{aligned}
& \begin{array}{llllll}
1.007 & 3.221 & 3.009 & -3.723 & -2.294 & -0.109
\end{array} \\
& +0.33 \text { GROWTH }-0.0123 \text { CREDIT }-0.249 \text { PAYG + 2.083 DEP }-2.671 \text { DEP-1 }_{-1} \\
& \begin{array}{lllll}
4.754 & -1.186 & -1.160 & 1.978 & -2.988
\end{array}
\end{aligned}
$$

Diagnostic Tests:

$\bar{R}^{2}=0.934, \mathrm{DW}=2.76, \mathrm{SE}$ of regression $=0.3975, \mathrm{RSS}=1.7381$,

AR1 $F(1,10)=2.805[0.128]$, Normality $\chi^{2}(2)=0.5547$ [0.758],

RESET $\mathrm{F}(1,10)=0.691[0.425]$, Heteroscedasticity $\mathrm{F}(1,20)=0.0829[0.776]$

Equation (3) passes all the diagnostic tests reported above (with probability values in square brackets) and the $\bar{R}^{2}$ value is quite high.

The long-run model of the corresponding ARDL model is derived in the equation below, displaying the long-run coefficient estimates with t-values. The long-run coefficients corresponding to this ARDL model are shown as Equation (4) below (with t-values in parentheses).

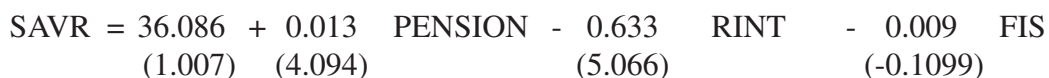

$$
\begin{aligned}
& \begin{array}{rrrrr}
0.33 & \text { GROWTH }-\underset{(-1.186)}{0.012} & \text { CREDIT }-\underset{(-1.249}{0} & \text { PAYG }-0.588 & \text { DEP } \\
(4.754) & (-0.489) &
\end{array}
\end{aligned}
$$

The signs and magnitudes of the coefficients are all compatible with the model outlined in this paper. The long-run coefficient estimates of PENSION, RINT, and GROWTH in [3] are significant at less than a one percent significance level. The coefficient on PENSION is an estimate of the parameter $\left(1-\alpha_{2}\right)$ in equation (1). Based on the Wald test, $\left[\chi^{2}(1)=16.76\right.$ $(0.00)]$, we reject the null hypothesis that $\left(1-\alpha_{2}\right)=0$, meaning that institutional retirement savings and other savings are not perfect substitutes. Our estimated long-run coefficient $s$ implies that with a one unit ( $£$ million) increase in pension savings per worker, aggregate savings in the UK increase by 0.013 percent, while other savings decline by 0.987 percent. In other words, there is close but not perfect substitution between pension funds and other forms of savings, in the sense that any forced saving (such as non-DC-type pension contribution) can be offset either by borrowing or reducing discretionary saving. In addition, due to relative illiquidity of pension savings meaning that such savings cannot be withdrawn until retirement, there could be an offsetting effect on other savings with the increase in pension savings.

Ideally, the additional savings resulting from the introduction of privately funded pension schemes should find its way to the capital market, increasing the equity market capitalization. The PENSION variable is a proxy for that part of the market capitalization. Our finding suggests that, in the long run, higher pension savings relative to the working age population 
have a significant positive effect on national savings in the UK. At the same time, it suggests that any increase in anticipated pension benefits could also lead to a corresponding reduction in current non-pension savings. ${ }^{24}$

The estimated coefficient on FIS suggests that an increase in the government budget deficit tends to reduce national saving, but the estimate is not statistically significant. A rising dependency ratio (DEP) also has a negative effect on national saving. According to our results, national saving is negatively affected by an increase in the real interest rate (RINT), implying that wealth/income effects outweigh substitution effects. As pointed out earlier, the evidence in the literature is mixed with regard to the sign of the interest elasticity of saving. The estimated impact of CREDIT on savings supports the case of no liquidity constraints in the UK. In other words, easing of credit constraints because of financial sector development has contributed to a decline in national savings in the UK. Finally, the estimated coefficient on PAYG suggests that an increase in PAYG spending crowds out national saving, but the estimate is statistically insignificant. The effect of the dependency ratio on savings is negative in the long-term. The effect of FIS being negative remains in line with the Ricardian equivalence theory. Overall, we conclude that the long-run estimates are statistically robust.

\section{CONCLUSION}

This paper has aimed to estimate the relationship between aggregate saving rates and changes in funded pension wealth in the UK from 1978-2000, controlling for other factors that influence savings such as financial deepening, real interest rates, fiscal deficits, dependency ratio, and public pension spending. We found that higher pension assets are associated with a small net increase in national savings. The results should be treated with caution, however, given the relatively short sample size. Given lengthening life expectancy, there is no definitive answer for whether pre-funding of pension benefits offers a valid strategy to cope with massive fiscal burden associated with population ageing. ${ }^{25}$ Demographic pressures are likely to reduce savings in the long run, and government fiscal deficits in the UK seem to be offset by reduction in private savings. In this context, labour market flexibility could contribute to boosting the supply of labour and stabilizing the dependency ratio that remains just under 30 percent.

Notwithstanding, strong economic growth is the key to boosting national savings by reducing unemployment-related public spending. Lower growth in the OECD countries could lead to a surplus of private saving over private investment rather than a shortfall (presumably because of a reduced need for investment). Concerns about a future shortage of aggregate saving driving up interest rates should focus on the evolution of government budget balances rather than on private savings behaviour (Bosworth, 1995), thereby justifying our approach of examining the aggregate savings behaviour. Evidence suggests that privatization of pension savings may lead to a reduction in the pension burden on the national budget if combined with substantial cuts in benefits. Such reforms that lead to reductions in government expenditures on pension benefits and the fiscal balance may have a positive effect on

\footnotetext{
${ }^{24}$ This offsetting result partly corroborates existing empirical evidence that there is a considerable degree of private saving displacement by social security wealth (see Gale, 1998) in the sense that households implicitly view social security contributions as part of their compensation in future.

${ }^{25}$ In 1948, when the state pension was introduced, life expectancy at birth in the UK was 65.8 for men and 70.1 for women, which is now projected by the government to be 77.5 and 81.7 respectively by 2011 (UK Government Actuary Department).
} 
private savings, which could counterbalance the negative effects of privatization. For instance, according to Williamson (2002), the key negatives are higher administrative costs for the pension funds, exposure to stock market fluctuations, increased inequality, and potentially lower pension benefits for many low-wage workers.

The impact of pension reforms on domestic savings may not be uniform across countries. Even though this paper found that increased privately funded pensions in the UK increased aggregate savings marginally, investment in financial assets other than pensions may influence other savings in the capital market. Pension reforms indeed affect the market capitalization by channelling domestic long-term savings into the capital market, but along with encouraging the build-up of private pension assets, liberalization of financial services also facilitates households' access to credit, reducing their net savings. Even so, the increased liquidity and capitalization that private pension funds bring to the stock market could ultimately raise the level of national savings by promoting economic growth through more efficient resource allocation.

\section{Acknowledgements}

We are grateful to the participants of the Tokyo Club Research Conference, held in Tokyo on 3-4 December 2002, especially Barry Bosworth as the discussant of the paper, Akiko Nomura, and Donna Vandenbrink for their comments. We have also benefited from comments by Patrick Honohan, and Roman Zytek. All errors are our own.

\section{References}

Attanasio, O. P. and Banks, J. (2001) The assessment: household saving-issues in theory and policy, Oxford Review of Economic Policy, 17(1), 1-19.

Bailliu, J. and Reisen, H. (2000) Do funded pensions contribute to higher aggregate savings? A cross-country analysis. In Reisen, H. (Ed.) Pensions, Savings and Capital Flows: From Ageing to Emerging Markets. Cheltenham, Edward Elgar. p. 113-131.

Barr, N. (2002) The Pension Puzzle: Prerequisites and Policy Choices in Pension Design, Economic Issues 29 , Washington, DC: International Monetary Fund.

Barro, R. (1974) Are Government Bonds Net Wealth?, Journal of Political Economy, 82, 1095-117.

Blake, D. (2000) Two decades of pension reform in the UK: what are the implications for occupational pension schemes?, Employee Relations, 22(3), 223-245.

Booth, P. and Cooper, D. (2002) The tax treatment of UK defined contribution pension schemes, Fiscal Studies, 23(1), 77-104.

Börsch-Supan, A. and Brugiavini, A. (2001) Savings: the policy debate in Europe, Oxford Review of Economic Policy, 17(1), 116-143.

Bosworth, B. P. (1995) Prospects for Saving and Investment in Industrial Countries, Brookings Discussion Papers 113, Washington, DC: The Brookings Institution.

Catalan, M., Impavido, G. and Musalem, A. R. (2000) Contractual savings or stock market development: which leads?, Journal of Applied Social Science Studies, 120(3), 445-487.

Davis, E. P. (2001) The Regulation of Funded Pensions: A Case Study of the United Kingdom, Occasional Paper Series 15, London: Financial Services Authority.

Davis, E. P. (1996) Pension Fund Investments, In Steil, B. et al. The European Equity Markets: the State of the Union and an Agenda for the Millennium. London: The Royal Institute of International Affairs, 185-223.

Deaton, A. (1999) Saving and growth. In Schmidt-Hebbel, K. and Serven, L. (Eds) The Economics of Saving and Growth: Theory, Evidence, and Implications for Policy. Cambridge: Cambridge University Press, 33-70.

Deaton, A. (1992) Understanding Consumption (Clarendon Lectures in Economics). Oxford: Oxford University Press.

Disney, R., Emmerson, C. and Wakefield, M. (2001) Pension reform and saving in Britain, Oxford Review of Economic Policy, 17(1), 70-94.

Dutta, J., Kapur, S. and Orszag, J. M. (2000) A portfolio approach to the optimal funding of pensions, Economics Letters, 69, 201-206.

Edwards, S. (1996) Why are Latin America's savings rates so low? An international comparative analysis, Journal of Development Economics, 51(1), 5-44.

Feldstein, M. (1996) The missing piece in policy analysis: Social Security reform, The American Economic Review, 86(2), 1-14. 
Feldstein, M. (1974) Social security, induced retirement, and aggregate capital accumulation, Journal of Political Economy, 82(5), 18-23.

Gale, W. G. (1998) The Effects of Pensions on Household Wealth: a Re-evaluation of Theory and Evidence, Journal of Political Economy, 106(4), 706-723.

Hemming, R. (1999) Should public pensions be funded?, International Social Security Review, 52(2), 3-29.

Holzmann, R. (1997) Pension reform, financial market development, and economic growth: preliminary evidence from Chile, IMF Staff Papers, 44(2), 149-178.

Honohan, P. (1999) Financial Policies and Saving. In Schmidt-Hebbel, K. and Serven, L. The Economics of Saving and Growth: Theory, Evidence, and Implications for Policy. Cambridge: Cambridge University Press, 71-106.

Johansen, S. (1988) Statistical Analysis of Cointegration Vectors, Journal of Economic Dynamic and Control, 12, 231-254.

Johansen, S. (1996) Likelihood-based inference in Cointegrated Vector Autoregressive Models, 2nd printing. Oxford: Oxford University Press.

Masson, P. R., Bayoumi, T. and Samiei, H. (1998) International evidence on the determinants of private saving, The World Bank Economic Review, 12(3), 483-502.

Mesa-lago, C. (2002) Myth and reality of pension reform: the Latin American evidence, World Development, 30(8), $1309-1321$.

Muellbauer, J. and Murphy, A. (1997) Booms and busts in the UK housing market, The Economic Journal, 107(445), 1701-1727.

Myners, P. (2001) Institutional Investment in the United Kingdom: A Review. London: HM Treasury.

Organisation for Economic Cooperation and Development (OECD) (2002) OECD Economic Surveys: United Kingdom, 2002/1, Paris: OECD.

Orszag, P. and Stiglitz, J. (2001) Rethinking pension reform: ten myths about social security systems. In Holzmann, R. and Stiglitz, J. (Eds) New Ideas about Old Age Security: Toward Sustainable Pension Systems in the 21st Century. Washington, DC: The World Bank, 17-56.

Palley, T. I. (1998) The economics of social security: an old Keynesian perspective, Journal of Post Keynesian Economics, 21(1), 93-110.

Paxson, C. (1996) Saving and growth: evidence from micro data, European Economic Review, 40(2), 255-288.

Pesaran, M. H. and Pesaran, B. (1997) Working with Microfit 4.0: Interactive Econometric Analysis. Oxford: Oxford University Press.

Pesaran, M. H. and Shin, Y. (1999) An autoregressive distributed lag modelling approach to cointegration analysis. In Strom, S. (Ed.) Econometrics and Economic Theory in the 20th Century: The Ragnar Frisch Centennial Symposium. Cambridge: Cambridge University Press, Chapter 11.

Pickering, A. (2002) A Simpler Way to Better Pensions: An Independent Report. UK: Department for Work and Pensions.

Pitelis, C. (1997) On Kaldor and pensions, Cambridge Journal of Economics, 21(4), 469-482.

Samwick, A. (2000) Is pension reform conducive to higher saving?, Review of Economics and Statistics, LXXXII(2), 264-272.

Sandler, R. (2002) Medium and Long Term Retail Savings in the UK: A Review. London: HM Treasury.

Schmidt-Hebbel, K. and Serven, L. (Eds) (1999) Saving in the World: The Stylized Facts, In The Economics of Saving and Growth: Theory, Evidence, and Implications for Policy. Cambridge: Cambridge University Press, 6-32.

Vittas, D. (2002) Policies to promote saving for retirement: a synthetic overview, Working Paper No: 2801. Washington DC: World Bank.

Williamson J. B. (2002) Privatization of Social Security in the United Kingdom: warning or exemplar?, Journal of Aging Studies, 16(4), 415-430. 